\title{
PENGARUH JARAK ANTARA ELEMEN BATANG TEKAN GANDA TERHADAP KUAT TEKAN
}

\author{
Mudji Suhardiman', Arusmalem Ginting ${ }^{2}$, Herman $^{3}$ \\ ${ }^{1,2}$ Dosen Tetap, Jurusan Teknik Sipil, Fakultas Teknik, Universitas Janabadra \\ ${ }^{3}$ Alumnus Jurusan Teknik Sipil, Fakultas Teknik,Universitas Janabadra, Yogyakarta \\ Jl. Tentara Rakyat Mataram No. 55-57, Yogyakarta \\ E-mail : agintm@yahoo.com
}

\begin{abstract}
ABSTRAK
Kayu sering digunakan sebagai batang tekan pada kuda-kuda dan kolom. Untuk mendukung beban besar dibutuhkan dimensi batang tekan tunggal cukup besar. Batang tekan tunggal dapat diganti dengan batang tekan ganda yang terdiri dari dua atau lebih elemen batang yang digabung menjadi satu kesatuan. Jarak antara elemen mengakibatkan bertambah besarnya momen inersia terhadap sumbu bebas bahan yang berada diantara kedua tampang elemen tersebut. Secara teoritis semakin jauh jarak antara akan meningkatkan daya dukung, tetapi semakin tidak terjamin kerja sama antara elemen-elemen sebagai satu kesatuan. Berdasarkan PKKI 1961 besarnya jarak antara $\leq 2$ kali tebal elemen batang tekan. Berdasarkan uraian tersebut perlu dilakukan penelitian tentang pengaruh jarak antara elemen batang tekan ganda terhadap kuat tekan. Penelitian ini menggunakan kayu Keruing dengan dimensi 2 × 3/10 panjang $2 \mathrm{~m}$. Jarak antara elemen batang tekan ganda yang digunakan adalah $0,1.5,3,4.5$ dan $6 \mathrm{~cm}$. Jumlah benda uji setiap variasi jarak antara 1 buah, dengan total benda uji sebanyak 5 buah. Hubungan antara elemen batang tekan ganda menggunakan alat sambung baut. Kondisi ujung-ujung benda uji berupa sendi. Pembebabanan yang diberikan adalah beban sentris yang diberi secara bertahap. Dari hasil pengujian ini akan didapat data beban dan lendutan. Sebelum dilakukan pengujian batang tekan ganda terlebih dahulu dilakukan pengujian specimen batang tekan kayu Keruing dengan ukuran 5 × 5 × $20 \mathrm{~cm}$ sebanyak 5 buah. Dari hasil penelitian ini didapat tegangan tekan rata-rata kayu Keruing sebesar 377,144 $\mathrm{kg} / \mathrm{cm}^{2}$. Kuat tekan batang ganda maksimum terjadi pada jarak antara 1,5 kali tebal kayu atau 4,5 $\mathrm{cm}$. Pada jarak antara batang tekan ganda 2 kali tebal kayu atau $6 \mathrm{~cm}$ mulai mengalami penurunan, tetapi hasil ini masih lebih tinggi dari batang tekan ganda yang tanpa jarak antara. Hasil pengujian batang tekan ganda lebih kecil dari hasil perhitungan teoritis dengan menggunakan tegangan absolut yang didapat dari pengujian tekan specimen, dan lebih besar dari hasil perhitungan teoritis dengan menggunakan tegangan ijin tekan kayu berdasarkan PKKI 1961. Dari hasil penelitian ini tegangan ijin tekan pada PKKI 1961 aman untuk digunakan pada perhitungan batang tekan ganda.
\end{abstract}

Kata kunci : kayu Keruing, batang tekan ganda, jarak antara.

\begin{abstract}
Wood is often used as compression chords in trusses and as the column in frame construction. The large dimension of a single solid compression member is needed to support the heavy load action. A single solid compression member can be replaced with spaced column that built up two or more individual members (shafts) that was joined together. Space between shafts increase moment of inertia to spaced column axis between shafts. Theoretically, increasing space between shafts will increase supporting ability of the column, but increasing differential movement between the shafts. Based on PKKI 1961, the clear space between the individual shafts should be less or equal than two times of single shaft thickness. From this analysis, influence of space between shafts to axial compressive strength must be researched. This research used Keruing wood with 2 × 3/10 dimension and $2 \mathrm{~m}$ long. Space between shafts of two-shaft spaced column that was used 0, 1.5, 3, 4.5 and $6 \mathrm{~cm}$. Each variation space between shafts was used one sample, and totally five samples. Both of shafts were joined together by bolt. Restrained at both ends were pinned. Axial concentric load was increased gradually. From the results of this testing will be gotten axial compressive load and lateral deflection data. Before carried out testing of two-shaft spaced column, axial
\end{abstract}


compressive strength testing to five specimens of Keruing wood with $5 \times 5 \times 20 \mathrm{~cm}$ dimension was conducted. From the result of this research was gotten average compressive strength the Keruing wood was $377.144 \mathrm{~kg} / \mathrm{cm}^{2}$. The maximum compressive strength of two-shaft spaced column was occur in the space 1,5 times of a single shaft thickness or 4,5 cm. In the space 2 times of a single shaft thickness or $6 \mathrm{~cm}$, compressive strength began to descend, but still higher than the two-shaft spaced column without space between the individual shafts. The testing result of two-shaft spaced column was smaller than the result of the theoretical calculation by using the absolute stress that was obtained from the compressive strength testing of specimen, and bigger than the result of the theoretical calculation by using the permissible stress was based on PKKI 1961. From the result of this research, the permissible stress on PKKI 1961 was safe to be used in the calculation of the two-shaft spaced column.

Key words : Keruing wood, two-shaft spaced column, space between shafts.

\section{PENDAHULUAN}

Umur tebang pohon kayu cukup lama dan lahan hutan yang semakin berkurang mengakibatkan persedian kayu untuk struktur yang berkualitas baik dan berdimensi besar semakin menipis. Perancangan yang kurang tepat dan penggunaan faktor aman yang terlalu besar mengakibatkan pemborosan kayu. Dengan pengetahuan dan penelitianpenelitian tentang kekuatan dan sistim perancangan struktur kayu maka masih dimungkinkan dilakukan penghematan penggunaan kayu. Kayu sering digunakan sebagai batang tekan pada kuda-kuda dan kolom. Pada batang tekan harus diperhitungkan adanya bahaya tekuk yang besarnya dipengaruhi oleh kelangsingan batang. Batang tekan tersebut dapat berupa batang tekan tunggal maupun batang tekan ganda. Untuk mendukung beban besar dibutuhkan dimensi batang tekan tunggal yang cukup besar. Dimensi kayu yang cukup besar belum tentu tersedia di pasaran, sehingga dapat diganti dengan batang tekan ganda yang terdiri dari dua atau lebih elemen batang digabung menjadi satu kesatuan. Keuntungan penggunaan batang tekan ganda adalah sebagai berikut: dapat menggunakan kayu berdimensi kecil, meningkatkan daya dukung karena bertambahnya momen inersia, dan penggabungan dapat dilakukan dengan cara sederhana menggunakan alat sambung baut atau paku.

Penggabungan elemen batang tekan dilakukan dengan menggunakan klos perangkai yang ditempatkan antara elemen batang tekan dan diikat dengan alat sambung. Jarak antara elemen setebal klos perangkai tersebut mengakibatkan bertambah besarnya momen inersia terhadap sumbu bebas bahan yang berada diantara kedua tampang elemen tersebut. Secara teoritis semakin jauh jarak antara akan meningkatkan daya dukung akibat bertambah besarnya momen inersia, tetapi semakin tidak terjamin kerja sama antara elemen-elemen sebagai satu kesatuan.

Berdasarkan Peraturan Konstruksi Kayu Indonesia (PKKI 1961) besarnya momen inersia yang diperhitungkan terhadap sumbu bebas bahan sebesar $I_{\text {koreksi }}=1 / 4$. $\left(I_{t}\right.$ 
+ 3. $I_{g}$ ), dengan $I_{t}$ adalah momen inersia teoritis dan $I_{g}$ adalah momen inersia geser dengan anggapan elemen tampang berimpit. Berdasarkan peraturan tersebut tidak ada faktor reduksi terhadap $I_{\text {koreksi }}$ sampai jarak antara sebesar dua kali tebal elemen batang tekan. Berdasarkan uraian tersebut perlu dilakukan penelitian tentang pengaruh jarak antara elemen batang tekan ganda terhadap kuat tekan, sehingga dapat diketahui batasan jarak antara yang optimum, dan perbandingan kuat tekan batang ganda berdasarkan perhitungan teoritis dan eksperimen.

\section{TINJAUAN LITERATUR}

Kayu keruing masuk dalam famili Dipterocarpaceae yang mempunyai lebih dari 15 spesies tumbuh di hutan-hutan daerah tropis. Kayu keruing mempunyai tingkat kekuatan III atau II dengan berat jenis 0,6 - 0,9. Tingkat keawetan kayu keruing adalah tingkat III dan tingkat pemakaiannya adalah tingkat III, sehingga dapat digunakan untuk keperluan konstruksi berat terlindung. Daya retak kayu keruing kecil, tetapi kembang susut akibat cuaca cukup besar. Kayu keruing tidak tahan rayap dan mudah lapuk (Wiryomartono, 1976). Berdasarkan PKKI 1961 tingkat kekuatan kayu dibagi menjadi beberapa kelas kuat seperti pada Tabel 1. Tegangan ijin berdasarkan kelas kuat kayu seperti ditunjukkan pada Tabel 2 (PKKI, 1961).

Tabel 1. Tingkat kekuatan kayu.

\begin{tabular}{cccc}
\hline Kelas kayu & Berat jenis & $\begin{array}{c}\text { Kukuh lentur mutlak } \\
\mathrm{kg} / \mathrm{cm}^{2}\end{array}$ & $\begin{array}{c}\text { Kukuh tekan mutlak } \\
\mathrm{kg} / \mathrm{cm}^{2}\end{array}$ \\
\hline I & $>0,90$ & $>1100$ & $>650$ \\
\hline II & $0,90-0,60$ & $1100-725$ & $650-425$ \\
\hline III & $0,60-0,40$ & $725-500$ & $425-300$ \\
\hline IV & $0,40-0,30$ & $500-360$ & $300-215$ \\
\hline V & $<0,30$ & $<360$ & $<215$ \\
\hline
\end{tabular}

Tabel 2. Tegangan ijin kayu.

\begin{tabular}{rcccccc}
\hline & \multicolumn{5}{c}{ Kelas Kuat } & Jati \\
\cline { 2 - 5 } & I & II & III & IV & V & (Tectanograndis) \\
\hline$\sigma_{\mathrm{lt} / /}\left(\mathrm{kg} / \mathrm{cm}^{2}\right)$ & 150 & 100 & 75 & 50 & - & 130 \\
$\sigma_{\mathrm{t} \mathrm{t} / /}\left(\mathrm{kg} / \mathrm{cm}^{2}\right)$ & 130 & 85 & 60 & 45 & - & 110 \\
$\sigma_{\mathrm{tk} \perp}\left(\mathrm{kg} / \mathrm{cm}^{2}\right)$ & 40 & 25 & 15 & 10 & - & 30 \\
$\tau_{/ /}\left(\mathrm{kg} / \mathrm{cm}^{2}\right)$ & 20 & 12 & 8 & 5 & - & 15 \\
\hline
\end{tabular}

Kuat tekan suatu jenis kayu adalah kekuatan kayu untuk menahan muatan jika kayu itu dipergunakan untuk penggunaan tertentu. Kuat tekan dibedakan menjadi dua 
macam yaitu kuat tekan tegak lurus arah serat dan sejajar arah serat. Kuat tekan tegak lurus arah serat pada semua kayu lebih kecil daripada kuat tekan sejajar arah serat (Dumanauw, 1990). Berdasarkan SNI 03-3958-1995, dimensi benda uji kuat tekan kayu sebesar 50 × 50 × $200 \mathrm{~mm}$. Pengujian kuat tekan kayu dilakukan dengan meletakkan benda uji sentris terhadap alat pembebanan. Kuat tekan kayu dihitung berdasarkan beban maksimum dan luas penampang.

Menurut Soehendradjati (1990), batang desak pada struktur rangka, kolom, maupun stuktur bangunan yang lain, selalu terjadi kemungkinan tertekuk. Pada batang tekan dengan kelangsingan $\lambda>10$ sangat terpengaruh oleh tekuk. Pada perhitungan batang tekan, perlemahan tampang akibat alat sambung tidak perlu diperhitungkan seperti pada batang tarik. Lubang diperhitungkan sebagai perlemahan jika di tengah batang terdapat lubang-lubang yang tidak tertutup. Pada struktur rangka, banyak dijumpai batang tekan yang menggunakan batang ganda. Selain untuk stabilitas sambungan, batang ganda juga untuk menambah kekuatan mendukung gaya tekan. Kekuatan batang tekan dipengaruhi oleh momen inersia (I) atau jari-jari inersia (i). Momen inersia dan jari-jari inersia menjadi lebih besar jika bagian tampang jauh dari titik pusat tampang. Selain dipakai untuk struktur rangka, batang ganda juga sering dipakai untuk kolom. Pada tampang batang ganda dibedakan dua macam sumbu, yaitu sumbu bahan dan sumbu bebas bahan. Sumbu bahan adalah sumbu yang memotong tampang, sedangkan sumbu bebas bahan adalah sumbu yang tidak memotong tampang. Pada batang ganda yang secara teoritis besarnya momen inersia $\mathrm{I}_{\mathrm{x}}=\mathrm{I}_{\mathrm{y}}$, tertekuknya batang ganda terjadi lebih dulu pada arah tegak lurus sumbu bebas bahan. Karena itu momen inersia terhadap sumbu bebas bahan harus diberi faktor reduksi.

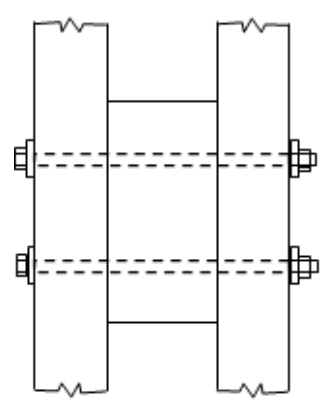

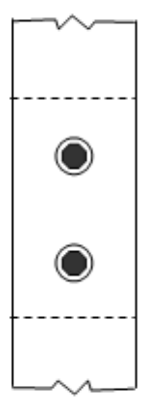

$\leq 18 \mathrm{~cm} \mid$
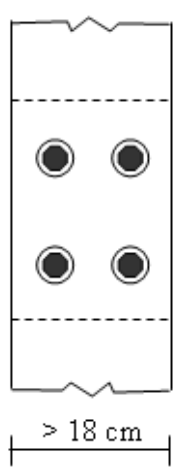

Gambar 1. Penempatan perangkai.

Berdasarkan PKKI 1961 jarak antara masing-masing bagian tampang batang ganda tidak boleh lebih besar dari 2 kali lebar tampang, tetapi jika jarak antara masing- 
masing bagian lebih besar dari dua kali lebar tampang maka didalam perhitungan diperhitungkan sama dengan dua kali lebar tampang. Batang ganda diberi perangkai (Gambar 1) pada ujung-ujungnya dan juga pada dua titik yang berjarak $1 / 3$ panjang bentang dari ujung-ujung. Jika lebar bagian masing-masing tampang ganda $b<18 \mathrm{~cm}$ dipakai 2 batang baut, dan jika $\mathrm{b}>18 \mathrm{~cm}$ dipakai 4 batang baut. Untuk batang yang menahan tegangan tekan, panjang tekuk $\left(l_{k}\right)$ diambil sebesar jarak antara 2 titik yang berurutan yang bebas dari tekukan.

Menurut Gere dan Timoshenko (2000), panjang efektif (panjang tekuk) kolom dengan berbagai jenis tumpuan pada ujung-ujungnya adalah sebagai berikut:

a. kolom dengan tumpuan kedua ujungnya berupa sendi, $1_{k}=1$ dengan 1 adalah panjang kolom

b. kolom dengan tumpuan ujungnya berupa jepit dan bebas, $1_{\mathrm{k}}=2.1$

c. kolom dengan tumpuan kedua ujungnya berupa jepit, $1_{\mathrm{k}}=0,5.1$

d. kolom dengan tumpuan ujungnya berupa jepit dan sendi, $1_{k}=0,699.1$

Berdasarkan PKKI 1961, angka kelangsingan $(\lambda)$ adalah panjang tekuk $\left(l_{k}\right)$ dibagi dengan jari-jari inersia minimum $\left(i_{\text {min }}\right)$. Pada batang tekan besarnya angka kelangsingan tidak boleh lebih besar dari 150 . Untuk menghindari bahaya tekuk pada batang tekan maka gaya yang didukung harus digandakan dengan suatu faktor tekuk $(\omega)$ seperti pada Daftar III PKKI 1961.

Langkah-langkah perhitungan batang ganda yang terdiri dari 2 tampang berdasarkan PKKI 1961 adalah seperti pada uraian berikut ini.

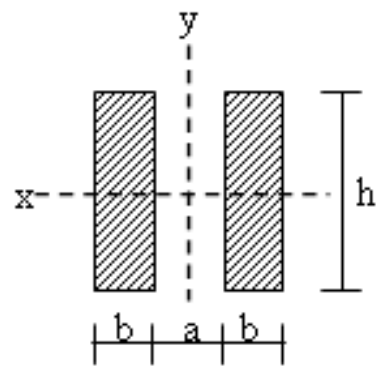

Gambar 2. Tampang batang ganda.

Batang ganda yang terdiri dari 2 tampang dengan panjang 1 , tebal kayu $\mathrm{b}$, tinggi kayu $\mathrm{h}$ dan jarak antara a. Besarnya momen inersia terhadap sumbu $\mathrm{x}$ adalah seperti pada Persamaan 1. 


$$
\mathrm{I}_{\mathrm{x}}=2 \cdot \frac{1}{12} \cdot \mathrm{b} \cdot \mathrm{h}^{3}
$$

Besarnya jari-jari inersia terhadap sumbu $x$ dengan $F_{b r}=2 . b . h$ adalah seperti Persamaan 2. berikut ini.

$$
\mathrm{i}_{\mathrm{x}}=\sqrt{\frac{I_{x}}{F_{b r}}}=\sqrt{\frac{2 \cdot \frac{1}{12} \cdot b \cdot h^{3}}{2 \cdot b \cdot h}}=0,289 \cdot \mathrm{h}
$$

Momen inersia teoritis terhadap sumbu y adalah seperti pada Persamaan 3. berikut ini.

$$
I_{t}=2 \cdot\left(\frac{1}{12} \cdot h \cdot b^{3}\right)+2 \cdot b \cdot h \cdot\left(\frac{1}{2} b+\frac{1}{2} a\right)^{2}
$$

Momen inersia geser terhadap sumbu y adalah momen inersia yang didapat dengan anggapan masing-masing bagian digeser hingga berimpit satu sama lain. Besarnya momen inersia geser adalah seperti Persamaan 4. berikut ini.

$$
\mathrm{I}_{\mathrm{g}}=\frac{1}{12} \cdot \mathrm{h} \cdot(2 \cdot \mathrm{b})^{3}
$$

Untuk menghitung besarnya momen inersia terhadap sumbu bebas bahan (sumbu y) digunakan Persamaan 5. berikut ini.

$$
\mathrm{I}_{\mathrm{y}}=\frac{1}{4} \cdot\left(\mathrm{I}_{\mathrm{t}}+3 \cdot \mathrm{I}_{\mathrm{g}}\right)
$$

Besarnya jari-jari inersia terhadap sumbu y adalah seperti Persamaan 6. berikut ini.

$$
\mathrm{i}_{\mathbf{y}}=\sqrt{\frac{I_{y}}{F_{b r}}}
$$

Besarnya jari-jari inersia minimum $\left(i_{\text {min }}\right.$ ) adalah nilai terkecil dari $i_{x}$ dan $i_{y}$ yang didapat dari Persamaan 2. dan 6. Panjang tekuk $\left(l_{k}\right)$ untuk batang tekan yang tumpuan kedua ujungnya berupa sendi sama dengan panjang batang tekan (1). Besarnya angka kelangsingan $(\lambda)$ didapat dari Persamaan 7. berikut ini.

$$
\lambda=\frac{l_{k}}{i_{\min }}
$$

Faktor tekuk $(\omega)$ didapat dari Daftar III PKKI 1961 yang besarnya tergantung dari besarnya $\lambda$.

Besarnya tegangan $(\sigma)$ yang terjadi pada batang tekan tampang ganda akibat beban P yang bekerja pada batang tekan tersebut adalah seperti pada Persamaan 8 . 


$$
\sigma=\frac{P . \omega}{F_{b r}}
$$

Jika dimensi batang tekan ganda sudah ditetapkan dan tegangan ijin diketahui, maka besarnya beban yang dapat didukung batang tekan ganda tersebut seperti pada Persamaan 9. yang didapat dari Persamaan 8 .

$$
\mathrm{P}=\frac{\sigma \cdot F_{b r}}{\omega}
$$

\section{CARA PENELITIAN}

\subsection{Benda Uji}

Benda uji yang digunakan pada penelitian ini terdiri dari benda uji kuat tekan specimen kayu keruing sebanyak 5 buah dengan ukuran 5 × 5 x $20 \mathrm{~cm}$ dan benda uji tekan batang ganda dengan ukuran $2 \times 3 / 10 \mathrm{~cm}$ dengan panjang $200 \mathrm{~cm}$. Jarak antara dibuat bervariasi yaitu: $0,1.5,3,4.5$, dan $6 \mathrm{~cm}$, jumlah benda uji setiap variasi jarak antara sebanyak 1 buah. Untuk lebih jelasnya benda uji batang tekan ganda ini dapat dilihat pada Tabel 3. dan Gambar 3. berikut ini.

Tabel 3. Benda uji batang tekan ganda.

\begin{tabular}{ccccc}
\hline No. & Benda Uji & $\begin{array}{c}\text { Dimensi } \\
(\mathrm{cm})\end{array}$ & $\begin{array}{c}\text { Jarak antara (a) } \\
(\mathrm{cm})\end{array}$ & $\begin{array}{c}\text { Jumlah } \\
\text { Benda Uji }\end{array}$ \\
\hline 1 & BU-1 & $2 \times 3 \times 10$ & 0 & 1 \\
\hline 2 & BU-2 & $2 \times 3 \times 10$ & 1,5 & 1 \\
\hline 3 & BU-3 & $2 \times 3 \times 10$ & 3,0 & 1 \\
\hline 4 & BU-4 & $2 \times 3 \times 10$ & 4,5 & 1 \\
\hline 5 & BU-5 & $2 \times 3 \times 10$ & 6,0 & 1 \\
\hline
\end{tabular}
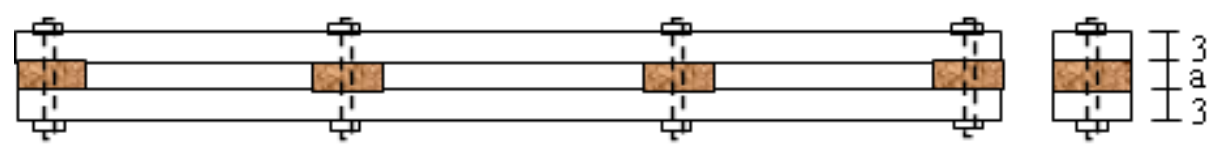

10
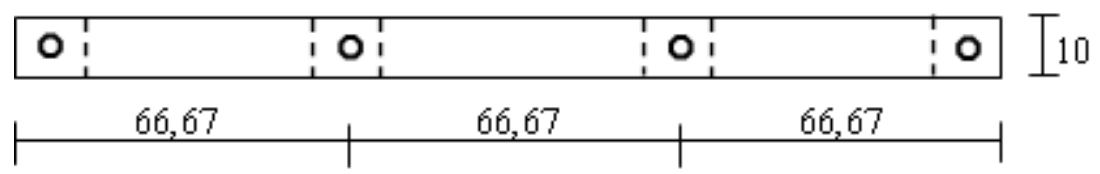

Gambar 3. Benda uji batang tekan ganda. 


\subsection{Pengujian Batang Tekan Ganda}

Benda uji yang digunakan adalah benda uji seperti pada Tabel 3. dan Gambar 3. dengan setting-up pengujian seperti pada Gambar 4. berikut ini.

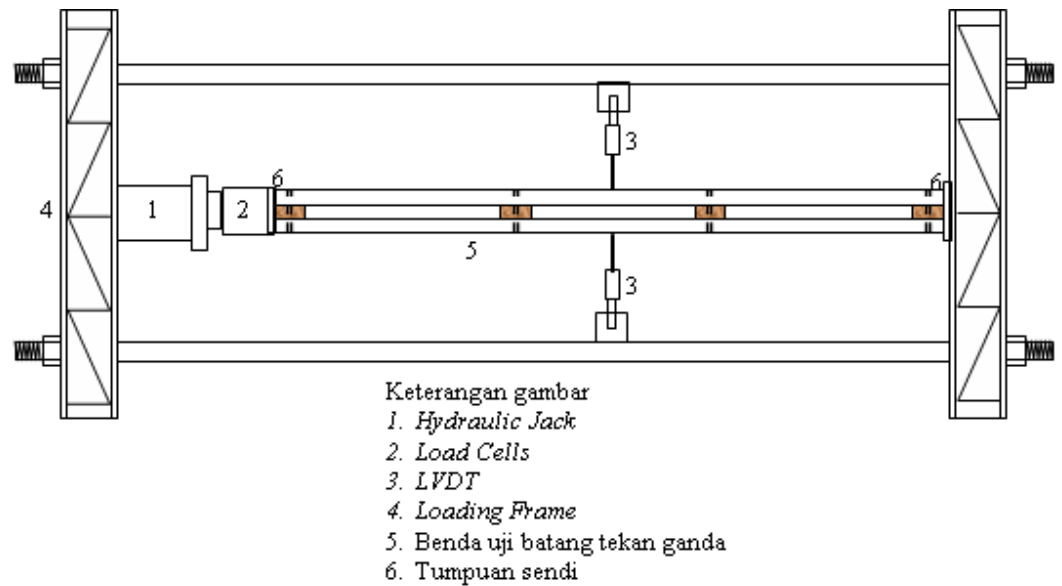

Gambar 4. Setting-up pengujian batang tekan ganda.

Batang tekan ganda yang sudah diletakkan pada loading frame dibebani secara bertahap hingga mencapai beban maksimum dan dihentikan setelah terjadi penurunan beban. Tahapan beban diberikan melalui hydraulic pump ke hydraulic jack dan diteruskan ke load cells. Besarnya beban yang diberikan terhadap benda uji dapat dibaca pada data logger yang dihubungkan dengan load cells, sedangkan besarnya lendutan di titik yang diukur dapat dibaca pada data logger yang dihubungkan dengan LVDT. Data beban lendutan yang tersimpan pada data logger dapat dicopy atau dapat juga diprint langsung dari data logger.

\section{HASIL DAN PEMBAHASAN}

\subsection{Kuat Tekan Specimen Kayu Keruing}

Hasil pengujian kuat tekan 5 buah specimen kayu Keruing seperti pada Tabel 4 . dan Gambar 5. berikut ini.

Tabel 4. Kuat tekan specimen kayu Keruing.

\begin{tabular}{cccccc}
\hline No. & $\begin{array}{c}\text { Benda } \\
\text { Uji }\end{array}$ & $\begin{array}{c}\text { Beban } \\
(\mathrm{Kg})\end{array}$ & $\begin{array}{c}\text { Luas } \\
\left(\mathrm{cm}^{2}\right)\end{array}$ & $\begin{array}{c}\text { Tegangan } \\
\left(\mathrm{kg} / \mathrm{cm}^{2}\right)\end{array}$ & $\begin{array}{c}\text { Tegangan rata- rata } \\
\left(\mathrm{kg} / \mathrm{cm}^{2}\right)\end{array}$ \\
\hline 1 & SPC-1 & 9310 & 25 & 372,40 & \\
\cline { 1 - 4 } 2 & SPC-2 & 8218 & 25 & 328,72 & \\
\cline { 1 - 4 } 3 & SPC-3 & 9881 & 25 & 395,24 & 377,144 \\
\cline { 1 - 4 } 4 & SPC-4 & 10414 & 25 & 416,56 & \\
\hline 5 & SPC-5 & 9320 & 25 & 372,80 & \\
\hline
\end{tabular}




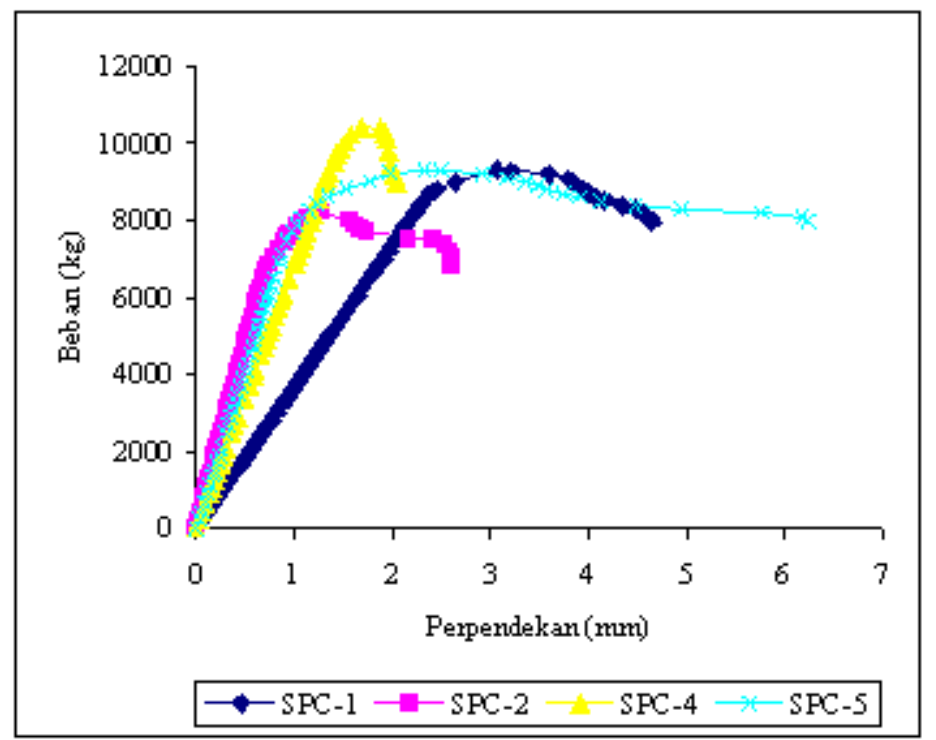

Gambar 5. Hubungan beban dan perpendekan kayu Keruing.

Dari Tabel 4. didapat tegangan tekan rata-rata kayu Keruing sebesar $377,144 \mathrm{~kg} / \mathrm{cm}^{2}$. Berdasarkan PKKI 1961 kayu Kruing termasuk kelas kuat II dengan kuat tekan absolut sebesar $425-650 \mathrm{~kg} / \mathrm{cm}^{2}$, dan kuat tekan ijin sebesar $85 \mathrm{~kg} / \mathrm{cm}^{2}$. Kuat tekan kayu Kruing hasil pengujian lebih rendah dari kuat tekan absolut, dan lebih besar dari kuat tekan ijin berdasarkan PKKI 1961 dengan faktor aman sebesar 4,44 .

\subsection{Kuat Tekan Batang Ganda}

Hasil pengujian kuat tekan batang ganda dengan jarak antara $0 ; 1,5 ; 3 ; 4,5$ dan 6 cm seperti pada Gambar 6. dan Tabel 5. Dari Tabel 5. dapat dilihat bahwa kuat tekan batang ganda mengalami peningkatan dengan bertambah besarnya jarak antara, hal ini disebabkan karena bertambahnya momen inersia. Kuat tekan batang ganda maksimum terjadi pada jarak antara 4,5 $\mathrm{cm}$ atau 1,5 kali tebal kayu. Pada jarak antara $6 \mathrm{~cm}$ atau 2 kali tebal kayu, kuat tekan batang ganda mengalami penurunan karena kayu tidak lagi bekerja secara bersamaan. Untuk lebih jelasnya perbandingan kuat tekan batang ganda ini dapat dilihat pada Gambar 7. 


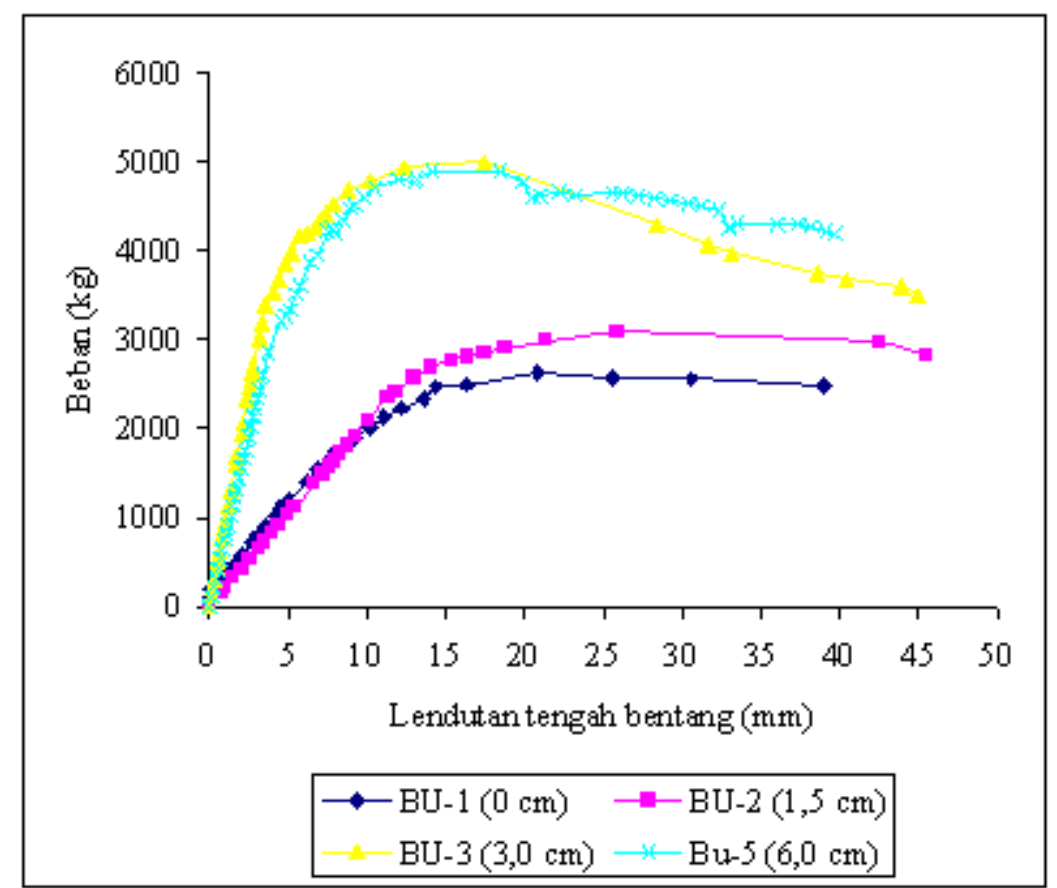

Gambar 6. Hubungan beban lendutan batang tekan ganda.

Tabel 5. Kuat tekan batang ganda.

\begin{tabular}{ccccc}
\hline No. & $\begin{array}{c}\text { Benda } \\
\text { Uji }\end{array}$ & $\begin{array}{c}\text { Jarak antara } \\
(\mathrm{cm})\end{array}$ & $\begin{array}{c}\text { Beban maksimum } \\
(\mathrm{kg})\end{array}$ & $\begin{array}{c}\text { Peningkatan kekuatan } \\
(\%)\end{array}$ \\
\hline 1 & BU-1 & 0 & 2628 & - \\
\hline 2 & BU-2 & 1,5 & 3090 & 17,58 \\
\hline 3 & BU-3 & 3,0 & 5002 & 90,33 \\
\hline 4 & BU-4 & 4,5 & 5608 & 113,39 \\
\hline 5 & BU-5 & 6,0 & 4903 & 86,57 \\
\hline
\end{tabular}

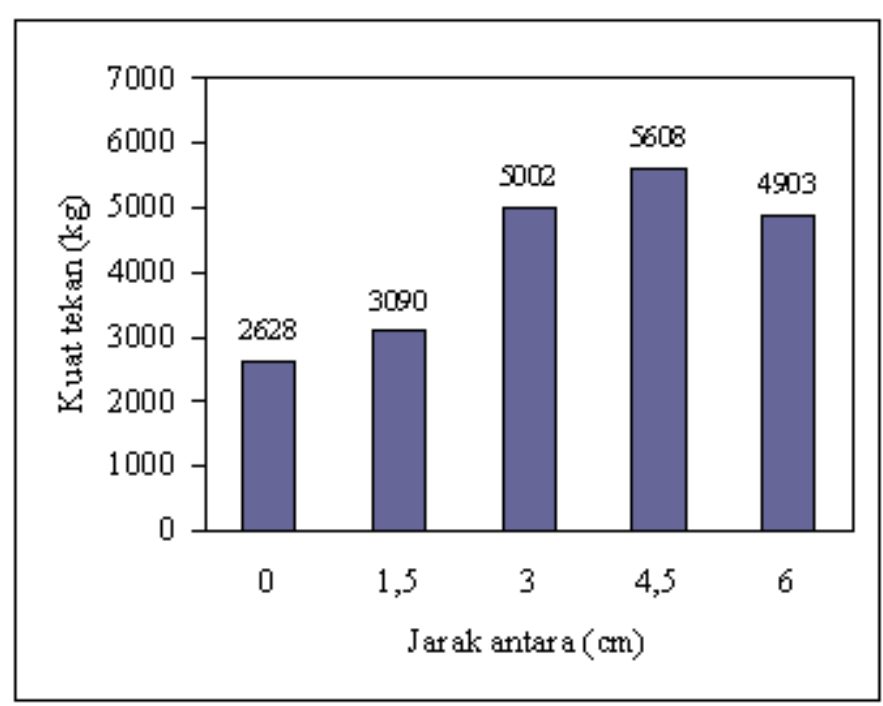

Gambar 7. Kuat tekan batang ganda. 
Kuat tekan maksimal terjadi pada batang ganda dengan jarak antara $4,5 \mathrm{~cm}$ dengan beban maksimal sebesar $5608 \mathrm{~kg}$ dengan peningkatan sebesar 113,39\%. Kuat tekan batang ganda pada jarak antara 1,5 cm mengalami peningkatan kekuatan 17,58 \%, jarak antara $3 \mathrm{~cm}$ mengalami peningkatan 90,33\%, jarak antara $6 \mathrm{~cm}$ mengalami peningkatan $86,57 \%$ jika dibandingkan dengan batang ganda tanpa jarak antara. Berdasarkan PKKI 1961 jarak antara masih diijinkan sampai 2 kali tebal kayu, dalam hal ini diijinkan sampai $6 \mathrm{~cm}$. Dari uraian di atas dapat disimpulkan bahwa daya dukung batang tekan ganda maksimum terjadi pada jarak antara 1,5 kali tebal kayu, dan pada jarak antara 2 kali tebal kayu mulai terjadi penurunan. Lendutan yang terjadi pada batang tekan ganda dapat dilihat pada Gambar 8 .

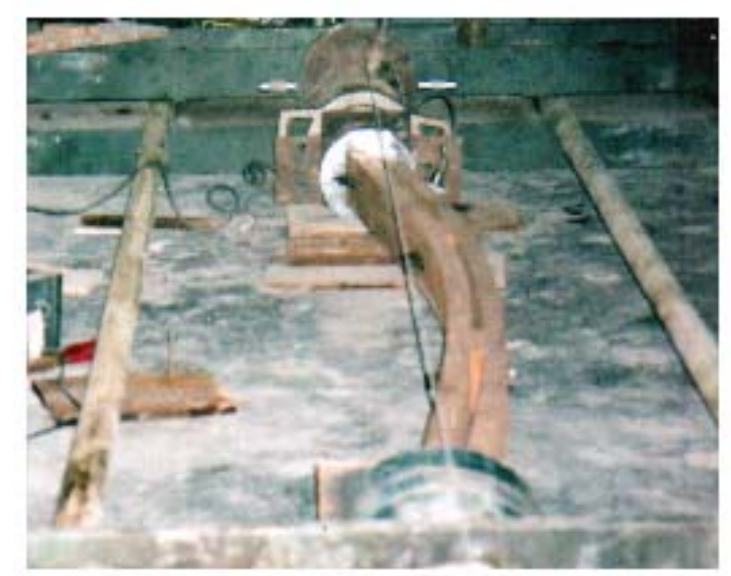

Gambar 8. Lendutan pada batang tekan ganda.

\subsection{Hasil Perhitungan Teoritis}

Kuat tekan batang ganda secara teoritis berdasarkan tegangan hasil pengujian specimen sebesar $\sigma_{\mathrm{abs}}=377,144 \mathrm{~kg} / \mathrm{cm}^{2}$, dan tegangan ijin kayu Keruing berdasarkan PKKI 1961 dengan $\bar{\sigma}=85 \mathrm{~kg} / \mathrm{cm}^{2}$ adalah seperti pada Tabel 6. berikut ini.

Tabel 6. Kuat tekan teoritis batang ganda.

\begin{tabular}{ccc}
\hline \multirow{2}{*}{$\begin{array}{c}\text { Jarak antara } \\
(\mathrm{cm})\end{array}$} & \multicolumn{2}{c}{ Kuat tekan teoritis batang ganda $(\mathrm{kg})$} \\
\cline { 2 - 3 } & $\begin{array}{c}\text { Berdasarkan } \\
\text { tegangan absolut }\end{array}$ & $\begin{array}{c}\text { Berdasarkan } \\
\text { tegangan ijin }\end{array}$ \\
\hline 0 & 5429,66 & 1223,73 \\
\hline 1,50 & 6909,30 & 1557,20 \\
\hline 3,00 & 8706,67 & 1962,29 \\
\hline 4,50 & 10244,77 & 2308,95 \\
\hline 6,00 & 11600,86 & 2614,58 \\
\hline
\end{tabular}




\subsection{Perbandingan Hasil Pengujian dan Teoritis}

Perbandingan kuat tekan batang ganda hasil pengujian dan hasil perhitungan secara teoritis seperti pada Tabel 7. dan Gambar 9. Dari Tabel 7. dan Gambar 9. dapat dilihat bahwa hasil pengujian batang tekan ganda lebih kecil dari hasil perhitungan teoritis dengan menggunakan tegangan absolut yang didapat dari pengujian tekan specimen. Hasil pengujian batang tekan dengan jarak antara 0 sebesar $48 \%$, jarak antara 1,5 sebesar $45 \%$, jarak antara $3 \mathrm{~cm}$ sebesar $57 \%$, jarak antara $4,5 \mathrm{~cm}$ sebesar $55 \%$ dan jarak antara $6 \mathrm{~cm}$ sebesar $42 \%$ dari hasil perhitungan teoritis batang tekan ganda menggunakan tegangan absolut. Hal ini karena pengaruh panjang batang tekan ganda yang mengakibatkan terjadinya tekuk, sehingga hasil pengujian yang didapat sekitar $50 \%$ dari perhitungan teoritis.

Dari Tabel 7. dan Gambar 9. didapat hasil pengujian batang tekan ganda lebih besar dari hasil perhitungan teoritis dengan menggunakan tegangan ijin tekan kayu berdasarkan PKKI 1961. Hasil pengujian batang tekan dengan jarak antara 0 sebesar $215 \%$, jarak antara 1,5 sebesar $198 \%$, jarak antara $3 \mathrm{~cm}$ sebesar $255 \%$, jarak antara 4,5 cm sebesar $243 \%$ dan jarak antara $6 \mathrm{~cm}$ sebesar $188 \%$ dari hasil perhitungan teoritis batang tekan ganda dengan tegangan ijin. Dari hasil ini dapat disimpulkan bahwa tegangan ijin tekan pada PKKI 1961 aman untuk digunakan pada perhitungan batang tekan ganda.

Tabel 7. Perbandingan kuat tekan batang ganda hasil pengujian dan perhitungan teoritis.

\begin{tabular}{|c|c|c|c|c|c|c|}
\hline \multirow{3}{*}{ No. } & \multirow{3}{*}{$\begin{array}{c}\text { Jarak } \\
\text { antara } \\
(\mathrm{cm})\end{array}$} & \multicolumn{3}{|c|}{ Kuat tekan batang ganda $(\mathrm{kg})$} & \multirow{3}{*}{\multicolumn{2}{|c|}{$\begin{array}{c}\text { Perbandingan hasil } \\
\text { pengujian dengan } \\
\text { perhitungan teoritis } \\
(\%)\end{array}$}} \\
\hline & & \multirow[b]{2}{*}{ Pengujian } & \multicolumn{2}{|c|}{ Perhitungan secara teoritis } & & \\
\hline & & & $\begin{array}{l}\text { Berdasarkan } \\
\text { tegangan absolut }\end{array}$ & $\begin{array}{l}\text { Berdasarkan } \\
\text { tegangan ijin }\end{array}$ & & \\
\hline$(1)$ & $(2)$ & (3) & (4) & $(5)$ & $(3) /(4)$ & $(3) /(5)$ \\
\hline 1 & 0 & 2628 & 5429,66 & 1223,73 & 48 & 215 \\
\hline 2 & 1,50 & 3090 & 6909,30 & 1557,20 & 45 & 198 \\
\hline 3 & 3,00 & 5002 & 8706,67 & 1962,29 & 57 & 255 \\
\hline 4 & 4,50 & 5608 & 10244,77 & 2308,95 & 55 & 243 \\
\hline 5 & 6,00 & 4903 & 11600,86 & 2614,58 & 42 & 188 \\
\hline
\end{tabular}




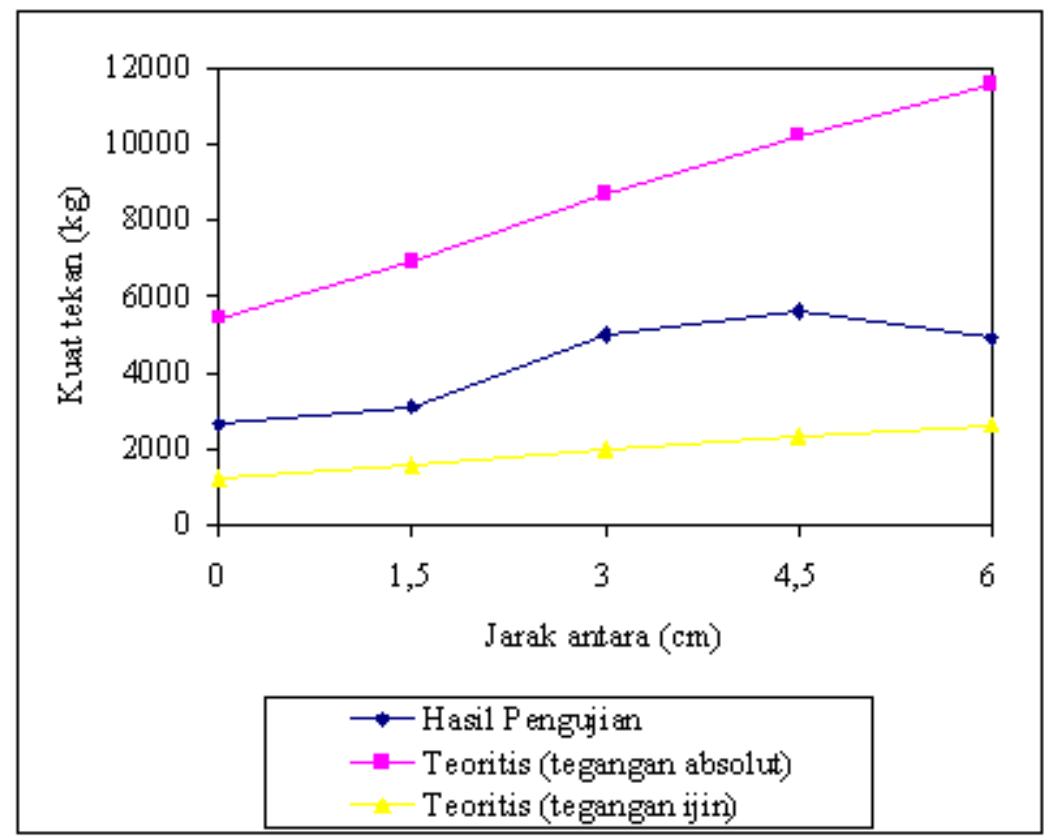

Gambar 9. Perbandingan kuat tekan batang ganda hasil pengujian dan perhitungan teoritis.

\section{KESIMPULAN DAN SARAN}

\subsection{Kesimpulan}

1. Tegangan tekan rata-rata kayu Keruing sebesar $377,144 \mathrm{~kg} / \mathrm{cm}^{2}$.

2. Kuat tekan batang ganda maksimum terjadi pada jarak antara 1,5 kali tebal kayu.

3. Kuat tekan batang ganda dengan jarak antara 2 kali tebal kayu mulai mengalami penurunan.

4. Hasil pengujian batang tekan ganda lebih kecil dari hasil perhitungan teoritis dengan menggunakan tegangan absolut yang didapat dari pengujian tekan specimen.

5. Hasil pengujian batang tekan ganda lebih besar dari hasil perhitungan teoritis dengan menggunakan tegangan ijin tekan kayu berdasarkan PKKI 1961.

6. Tegangan ijin tekan pada PKKI 1961 aman untuk digunakan pada perhitungan batang tekan ganda.

\subsection{Saran}

1. Jumlah benda uji untuk setiap variasi jarak antara perlu ditambah sehingga hasil yang didapat lebih teliti.

2. Perlu diteliti pengaruh perangkai terhadap batang tekan ganda. 


\section{DAFTAR PUSTAKA}

1. Anonim, 1961, Peraturan Konstruksi Kayu Indonesia 1961, Yayasan Lembaga Penyelidikan Masalah Bangunan.

2. Dumanauw, J.F., 1990, Mengenal Kayu, Pendidikan Industri Kayu Atas (Pika) Semarang, Kanisius, Yogyakarta.

3. Gere, J.M. dan Timoshenko, S.P., 2000, Mekanika Bahan, Jilid 2, Edisi Keempat, Erlangga, Jakarta.

4. SNI 03-3958, 1995, Metode Pengujian Kuat Tekan Kayu di Laboratorium, Balitbang, Kimpraswil, Jakarta.

5. Soehendradjati, R.J.B., 1990, Kayu untuk Struktur Jilid 1, Bahan Kuliah Jurusan Teknik Sipil, Fakultas Teknik, Universitas Gajah Mada, Yogyakarta.

6. Wiryomartono, S., 1976, Konstruksi Kayu, Bahan Kuliah Fakultas Teknik UGM, Yogyakarta. 